\title{
In vitro cultivation of pleomorphic Trypanosoma brucei stocks: a possible source of variable antigens for immunization studies
}

\author{
L. JENNI AND R. BRUN \\ Swiss Tropical Institute, CH-40:51 Basle, Switzerland
}

The number and pattern of variable antigen types (VAT) in metacyclic forms of Trypanosoma brucei and $T$. rhodesiense has been investigated by several workers (CUNNINGHAM, 1966; BARRY \& HAJDUK, 1979; JENNI, 1979). However, the degree of antigenic heterogeneity of metacyclic populations is still far from being clear. Further experiments have been carried out recently in order to analyse the pattern of metacyclic VAT which appeared in Glossina $m$. moristans during cyclical transmission of one stock of $T$. brucei.

\section{Material and Methods}

Trypanosoma brucei STIB 247 was isolated in 1971 in the Serengeti National Park (Tanzania) from a hartebeest (Alcelaphus buselaphus) and cryopreserved after one rat passage. For the last 13 months this primary isolate has been cyclically passaged through Glossina $m$. morsitans and SwissICR mice. Metacyclic populations were harvested and used as starting inoculum for continuous in vitro cultivation of vertebrate-infective forms according to BRUN et al. (1979). The feeder layer consisted of rabbit embryo fibroblast-like cells.

The neutralization of infectivity test was carried out as described by ScHLÄPPI \& JENNI (1977) by incubating $10^{4}$ trypanosomes per test. Rabbit antiserum against metacyclic VAT was prepared according to JENNI (1979).

In vitro cultured trypanosomes were harvested, centrifuged at $1000 \mathrm{~g}$ and the pellet resuspended in PSG buffer at $\mathrm{pH} 8 \cdot 0$. This suspension was then passed through a DEAE-cellulose column
(LANGHAM \& GODFREY, 1970) in order to separate the trypanosomes from detached feeder layer cells. The trypanosomes were irradiated with $50 \mathrm{krad}$ at 2 to $4^{\circ} \mathrm{C}$ by a ${ }^{60} \mathrm{Co}$ source in PSG and fresh rabbit serum. After irradiation, the trypanosomes were counted and injected intraperitoneally into 10 female Swiss-ICR mice $(25 \mathrm{~g}$ ) in equal amounts three times with no additional adjuvant (Table 1). Control animals were injected with the same amount of PSG and fresh rabbit serum as the test animals. One week after the last immunizing injection the mice were weekly challenged with one infective tsetse fly bite (Table I).

\section{Results and Discussion}

In vitro cultures were initiated with $10^{4}$ metacyclic forms per $\mathrm{ml}$ culture medium ( $1 \mathrm{ml}$ per well). After six hours the metacyclic forms transformed to slender-like bloodstream forms and after another six hours started to divide. After 50 hours a total trypanosome density (including parasites between feeder layer cells and in the supernatant medium) of $2 \cdot 7 \quad 10^{5}$ trypanosomes per well was normally reached.

The infectivity of metacyclic forms was completely neutralized by the rabbit antiserum. Daily tests with in vitro cultured parasites showed that the neutralizing activity of the antiserum was lost when the parasites had been in culture for more than 50 hours. After this growth period initial antigenic variation had occurred and new VAT were present within the parasite population which were not recognized by the antiserum. Thus for the in vitro culture trypanosomes were

Table I-Immunization of mice against the infective tsetse fly bite (T. brucei STIB 257))

\begin{tabular}{|c|c|c|c|c|c|c|c|c|}
\hline \multirow[b]{2}{*}{$\begin{array}{c}10 \\
\text { Test mice }\end{array}$} & \multicolumn{3}{|c|}{$\begin{array}{l}\text { IMMUNIZATION } \\
\text { No. of irradiated trypanosomes in- } \\
\text { jected per mouse at weekly intervals }\end{array}$} & \multicolumn{5}{|c|}{$\begin{array}{l}\text { TSETSE FLY CHALLENGE } \\
\text { No. of mice showing parasitaemia }\end{array}$} \\
\hline & $\begin{array}{c}6.5 \times 10^{4} \\
\text { Tryps in } \\
0.1 \mathrm{ml} \text { PSG } \\
+0.5 \% \mathrm{rs}\end{array}$ & $\begin{array}{c}1 \cdot 2 \text { a } 10^{4} \\
\text { Tryps in } \\
0 \cdot 1 \mathrm{ml} \text { PSG } \\
-2 \cdot 5 \% \text { rs }\end{array}$ & $\begin{array}{c}5 \cdot 0 \quad 10^{1} \\
\text { Tryps in } \\
0 \cdot 1 \mathrm{ml} \text { PSG } \\
1.0^{\circ} \mathrm{rs}\end{array}$ & $\begin{array}{c}\downarrow \\
0 / 10\end{array}$ & $0 / 10$ & $0 / 10$ & $0: 10$ & $0 / 10$ \\
\hline & & & & $\downarrow$ & & & & \\
\hline $\begin{array}{c}10 \\
\text { Control mice }\end{array}$ & $\begin{array}{l}0.1 \mathrm{ml} \text { PSG } \\
+0.5 \% \mathrm{rs}\end{array}$ & $\begin{array}{c}0 \cdot 1 \mathrm{ml} \text { PSG } \\
-1 \cdot 2 \cdot 5_{0}^{0} \mathrm{rs}\end{array}$ & $\begin{array}{c}0 \cdot 1 \mathrm{ml} \text { PSG } \\
-1 \cdot 0^{0}\end{array}$ & $\begin{array}{l}10 / 10 \\
72 \text { hrs } \\
\text { after bitc }\end{array}$ & $10 / 10$ & $10 / 10$ & $\begin{array}{c}7 / 10 \\
3 \text { mice } \\
\text { dead }\end{array}$ & $\begin{array}{l}\text { all mice } \\
\text { dead }\end{array}$ \\
\hline Days & 0 & 7 & 14 & 21 & 28 & 35 & 42 & 49 \\
\hline
\end{tabular}

$\downarrow \quad$ Challenge with one infective tsetse fly bite 
harvested 50 hours after initiation with metacyclic forms and used for immunization.

The mice were challenged each time with single infective flies which were taken at random from the infective fly pool in the laboratory. These flies derived from different transmission series with STIB 247 and were different from those flies from which the metacyclic forms were harvested for in vitro cultivation.

The tail blood of the challenged mice was examined by the haematocrit method. While the 10 test mice showed no parasitaemia after five infective bites all control mice showed parasites in the blood within 72 hours after the first challenge and died within four weeks (Table I).

Doyle et al., (1979). reported antigenic variation in $T$. brucei in vitro for the first time. Our results showed that this also occurred in vitro where trypanosomes directly derived from metacyclic forms were grown in the culture system described by BRUN et al. (1979). In addition, this system also allows the growth of clones from single metacyclic forms. These clones showed new VAT after eight days. However, new VAT appeared earlier in mice which have been cyclically infected. In these mice new VAT could already be detected 36 hours after the infective fly bite.

The above results show that initial antigenic variation in vitro is independent of the first cell divisions after the transformation from metacyclic to the slender-like bloodstream form. The results also show that metacyclic VAT can be quantitatively increased in vitro during a limited initial growth period. It is interesting to note that STIB 247 reverted during each fly passage to the same metacyclic VAT, for the immunized mice were completely protected against any metacyclic population of STIB 247. On the other hand, metacyclic VAT of other trypanosome stocks did infect mice immunized against metacyclic VAT of STIB 247. This is indicated by current experiments where mice immunized against STIB 247 are being challenged with flies infected with different $T$. brucei and $T$. congolense stocks.

\section{Acknowledgements}

This study was supported by the Swiss National Science Foundation, grant No. 3.346-0.78. We wish to thank $K$. F. Schell, $M$. Schönenberger and $M$. Kauffmann for skilful technical assistance. We are grateful to Drs. A. M. Jordan and L. W. Roberts for the supply of Glossina pupae.

\section{References}

Barry, J. D. \& Hajduk, S. L. (1979). Antigenic heterogeneity of bloodstream and metacyclic forms of T. brucei. In: Pathogenicity of Trypanosomes. Losos, G. \& Chouinard, A. (Editors). IDRC-132e, Ottawa, Canada, pp. 51-56.

Brun, R., Jenni, L., Tanner, M., Schönenberger, M. \& Schell, K.-F. (1979). Cultivation of vertebrate infective forms derived from metacyclic forms of pleomorphic Trypanosoma brucei stocks. Acta Tropica, 36, 387-390.

Cunningham, M. P. (1966). The preservation of viable metacyclic forms of Trypanosoma rhodesiense. Transactions of the Royal Society of Tropical Medicine and Hygiene, 60, 126.

Doyle, J. J., Hirumi, H. \& de Gee, A. L. W. (1979). Mechanisms of antigenic variation in salivarian trypanosomes. In: Pathogenicity of Trypanosomes Losos, G. \& Chouinard, A. (Editors). IDRC-132e, Ottawa, Canada, pp. 44-45.

Jenni, L. (1979). Cyclical transmission and antigenic variation. In: Pathogenicity of Trypanosomes. Losos, G. \& Chouinard, A. (Editors). IDRC-132e, Ottawa, Canada, pp. 49-50.

Lanham, S. M. \& Godfrey, D. G. (1970). Isolation of salivarian trypanosomes from man and other mammals using DEAE-cellulose. Experimental Parasitology, 28, 521-534.

Schläppi, B. \& Jenni, L. (1977). Studies on antigenic variation of cyclically transmitted Trypanosoma congolense. Acta Tropica, 34, 43-51. 